\title{
TEACHERS' TRAINING BY DISTANCE TEACHING METHOD: THE 15-YEAR EXPERIENCE AT KAUNAS UNIVERSITY OF TECHNOLOGY
}

\author{
Nijolė Bankauskienè \\ Lithuania \\ Ramunė Masaitytė \\ Lithuania
}

\begin{abstract}
The modern epoch raises greater and greater requirements for teachers' competence and qualification. So a pedagogue is obliged to constantly develop them. For 15 years Kaunas University of Technology has already provided teacher training by distance teaching method. In order to achieve the aim it has modern technical base and the teacher training programme "Pedagogical Studies". Considering the time and its requirements the programme content also changed. This article reviews the content and its change of the teacher training programme.
\end{abstract}

Keywords: distance teaching; mentor; Moodle system; Non-Degree Study Programme; programme "Pedagogical Studies"; tutor.

\section{Introduction}

Fast development of science and technologies, especially informatics and telecommunication stimulates the emergence of new forms of learning. One of them is distance learning. In the seventh decade of the last century the performed comprehensive researches on distant studies allowed understanding about peculiarities of distant studies as well as changing them, increasing their effectiveness. It has been perceived that distance studies are not only another form of studies but also another method of studies, which has specific features of programmes' design, formation of teaching material, interaction between an educator and student as well as their administration. As Rutkauskiené (2007) states, in order to effectively act in dynamic, fast changing society, it is necessary not only to constantly deepen one's knowledge, refresh qualification, develop one's competences but also to change one's professional activity. The need to constantly learn is being formed.

The European Union Commission - in the Lisbon conclusions on March 23, 2000 - pointed out that Europe moves to knowledge century. This will make great influence upon cultural, economic and social life of countries. The character of work, learning and the life will change. The Memorandum of Life- 
Nijole Bankauskienè, Ramune Masaitytè. Teachers' Training by Distance Teaching Method: the 15-Year Experience at Kaunas University of Technology

Long Learning was announced at October 30, 2000. Society pace and onceacquired education does not guarantee maintaining the even level of long-life wellbeing. One must constantly compete, refresh qualification. Thus the fundamental of long-life learning ideology, according to Rutkauskiené et al. (2003), is the transition from long-life learning to the process of long-life learning.

The sixth thesis of the above-mentioned memorandum induces to set learning near the home: to create learning conditions as close as to learners, their communities, where it is possible to install computer technologies. Thus distance studies become the tool for implementing the principle of long-life learning.

As Rutkauskienè (2007) indicates, having performed the PHARE project 'Multilateral Cooperation in Education Field', in 1998 the Lithuanian investment programme 'Lithuanian Distance Learning Network (lieDM, http://www.liedm.lt)' was started; it became the part of the general programme 'Information Technologies for Science and Studies (2001-2006)'.

Namely, mobility of higher education institutions allows speaking about peculiarities of distance studies. Distance institutional services 'are presented' for a student, the study conditions fitting their individual needs are created.

Keegan (1990), Ludlow (1994), Rumble (1997), Phare (2000), Willis (2000), Kraujutaitytė \& Pečkaitis (2003), Targamadzè et al. (1999), Targamadzè \& Petrauskienè (2008),Targamadzè (2011) emphasize that the form of distance studies is specific; thus the functions of distance studies' participants are also specific. Students' possibilities to directly communicate with teachers, organizers of distance studies and colleagues were limited enough. Consequently, as Kraujutaitytė \& Pečkaitis (2003) points out, such studies require academic competence from a student: self-control of thought and action while working individually, the ability to plan and systematically study.

Teachers face great workload while determining subject content during preparing the programme, teaching material and considering the particularity of distance studies. As Rowntree (1997), Willis (2000) point out, a teacher analyses the needs of students studying distantly as well as effectiveness of a module. $\mathrm{He} /$ She attempts to methodically disclose the subject content not only in printed but only sound, visual form, cares for smooth functioning of support system for a student in order to get feedback information on time.

As Freeman (1997), Willis (2000), Kraujutaitytė \& Pečkaitis (2003) state, engineers of distance studies perform the role of an assistant and moderator between a student and teacher. They have to get deeper into expectations of students and teachers, not to disappoint them, knowingly manage technologies for guaranteeing good quality picture and sound during studies. 
The aim of the article is to disclose the 15-year experience at KUT while training teachers by distance learning methods.

The aim is to be achieve by solving the following objectives:

1) Discuss the method of distance studies in training teachers at KUT.

2) Analyse the opinion of future teachers studying at the study programme 'Pedagogics Studies' about the studies by distance method.

\section{The method of distance studies in training teachers at KUT}

The programme of pedagogics studies started to be transmitted by distance method in autumn of 1999. So the era of distance learning started in Lithuanian studies' history. The programme was prepared on the basis of competence development so that students could get acquainted with general theoretical subjects, would develop special competences of a pedagogue, would acquire competences of research activity and subject delivery. During the first years the individuals, who finished studies of information technologies, chemistry, profession as well as economics and business fundamentals, learnt in this programme; they had bachelor's diplomas, but they did not have pedagogue's qualification. During one year of the studies, while learning by the distance method, they could acquire skills of pedagogue's activity. In this programme most attention was paid to theoretical disciplines because the teachers possessing large pedagogical experience of working at educational institutions studied in this programme. Only people working at educational institutions were admitted. The programme was constructed on the modular principle. Having studied one module, students moved to another module and the lectures were transmitted after their work at the particular hour by video conference method.

Lectures were transmitted from the Distance E-Studies Centre, KUT. One or two video transmission engineers took care of this. At the scheduled hour students gathered to distance learning classrooms, where the equipment of video receiving was installed. These classrooms were established in Klaipeda, Mažeikiai, Šiauliai, Panevėžys, Kèdainiai, Visaginas, Utena, Vilnius, Alytus, Marijampolè.

During lectures students saw the transmitted picture of a teacher and heard his / her voice. There was the possibility to demonstrate the teacher's table, blackboard, slides, and pictures, audio and video records. A teacher could see the video information transmitted from a distance classroom on the screen students, heard the questions they asked or saw the students' comments presented on the board. Some part of the delivered material was presented the printed form by the teacher before the lecture. Thus students did not have to take notes of the teacher's thoughts, they could only make notes of single remarks. 
Nijole Bankauskienè, Ramune Masaitytè. Teachers' Training by Distance Teaching Method: the 15-Year Experience at Kaunas University of Technology

During the lecture a teacher had to handle the auditorium, to know in what towns and how many students gathered in the classrooms of distance learning. Often lectures took place when a teacher did not see any student in front of himself / herself because they lived in remote places of Kaunas and used to come to established remote classrooms. Thus a teacher had to be able not only to present lecture material but also to ask questions, initiate discussions, motivate students.

Feedback between the studio, where a teacher works, and distant classrooms is maintained by the keyboard (the computer), voice (by the microphone), picture (the video camera). Feedback tools gave students the possibility to register, ask the teacher, give answers at interrogations, ask to repeat, show that students partly did not understand the material or everything is clear for them.

A teacher could give the possibility for the students to ask a question, which was heard in all distance learning classrooms, which at that time were connected to the distance studies centre in Kaunas. During the first years the distance lectures were transmitted only directly, lectures' records were not made.

However, students were satisfied with such not yet perfect learning form: they did not have to go to the lectures at KUT every week, they saved time and money, could study on-the-job. To KUT these students used to come to pass credits and examinations during the session as well as to defend their final projects.

This was the way the teachers, who pursued to acquire pedagogue's qualification used to study. When the implementation of teachers' training programme started in 1999-2001, students listened to the introductory course into distance studies and studied the following subjects: 'General Pedagogy', 'Personality and Development Psychology', 'Pedagogical and Development Psychology', 'Planning and Realization of Education Programmes', 'Planning of Action Research', 'Management of Education', 'Methodology of Action Research', 'Professional Pedagogy', 'Information Technologies of Teaching', 'Didactics'.

Later, from 2002 to 2009 the special professional study programme 'Pedagogy' changed its content either by expanding or reducing the amount of modules being delivered and the volume in credits; the programme was supplemented with new specializations, where the individuals delivering chemistry, information technologies, the Lithuanian language, foreign languages, technologies, economics and business fundamentals but not possessing pedagogue's qualification were studying. Thus 306 graduates, who got teacher's diploma, finished the programme from 1999 till 2009 and could successfully work at educational institutions. 
In 2010 the programme of teachers' training was reconstructed into the non-degree study programme (teacher studies). The number of study subjects, the teachers of which individuals with bachelor's subject qualification degree, was enlarged. The programme became non-cycle, non-degree, the $6^{\text {th }}$ qualification level. 259 individuals graduated from this programme and acquired pedagogue's qualification from 2010 to 2013 . It contained more study credits for pedagogical practice.

Professors, associated professors and lecturers, who had the pedagogical work experience at comprehensive schools, delivered subjects in this programme; they had qualification categories of a teacher supervisor, teacher expert, they knew teacher's activity and problems very well.

Internet transmissions of the lectures have started since 2010. All lectures are recorder and are installed in the Moodle system. The students can observe them during the transmission and get the records at the time convenient for them (after their work, at weekends), can come and observe lectures directly in the Distance E-Learning Centre.

Lectures' time has also expanded (from 10.30 to 19.30). The teachers not only deliver their lectures but also organize consultations; the students perform their interim-assignments and send them to the teachers by the Internet. However, the order for students to come to account for one's pedagogical practice and to the examination session as well as to defend one's final project still exists. The final project is prepared on the basis of action research by accumulating the material during the pedagogical practice.

Qualitatively new (60 study credits) non-degree one-year study programme was designed in 2014 and it was approved in 2015: it is the only teachers' training programme 'Pedagogy Studies' performed by this method in Lithuania; it is carried out on the level of theory (30 cr.) and practice $(30 \mathrm{cr}$.).It is carried out by half-distance method (only all theoretical subjects of the programme). The programme structure recomposed, the number of specializations increased (16). After transmission of the lectures, the subjects' material and lectures' records are placed in the Moodle system, where students find assignments presented by teachers and comments on the quality of the performed work as well as lectures' slides.

Accomplishment of the pedagogical practice refers to methodology of reverse mentorship, on computers the students observe several theoretical lectures on how to organize and perform their pedagogical practice, how to communicate with their mentors and tutors, how to write their practice diary as well as to prepare the practice report.

The students perform their pedagogical practice at educational institutions; the practice is observed by a mentor and controlled by a tutor - a KUT teacher. KUT teachers go to students' practice places, discuss the practice process; they 
Nijole Bankauskienè, Ramune Masaitytè. Teachers' Training by Distance Teaching Method: the 15-Year Experience at Kaunas University of Technology

discuss and evaluate results of student's practice together with the principal of the educational institution and the mentor. The individuals living and working in Spain, Belgium, and Ireland entered and graduated from the programme aimed to train teachers. 23 pedagogues graduated from this programme in the academic year of 2014-2015.

At present 34 students and 6 listeners study in the programme. It should be pointed out that the individuals, who at present are teachers, associated professors and professors of Lithuanian higher education institutions, studied at this programme and graduated from it. As well some of them work as principals of educational institutions, vice-principals for education; they are famous people, of culture, performers and actors, employees of informal education institutions and municipalities.

\section{The Research Results on Opinions of Students of Non-Degree Study Programme 'Pedagogy Studies" on Teachers' Training by Distant Method}

The research was performed in April 2015. The research sample consisted of 21 women and 2 men. 10 women and 1 man worked at educational institutions. 12 individuals (11 women and 1 man) worked at other noneducational institutions.

The approach of qualitative research was chosen. All 23 students, who were to graduate from the non-degree study programme 'Pedagogy Studies' took part in the qualitative research. All respondents were related to the research object (they studied at the study programme) and reflected as well as reviewed the problem formulated during the research: is it possible to state that Kaunas University of Technology accumulated certain experience in training teachers by distant method?

The research instrument (open questionnaire) was formed referring to generalizations in six types of questions by Patton $(1987,1990)$ and Rupšiené (2007):

1. about respondents' behaviour (what a respondent has done or what their actions and experience are);

2. what respondents' opinion is (what a respondent thinks about the analysed problem);

3. about respondents' feelings (what respondents feel);

4. about knowing and evaluation (what they know about the analysed problem, how respondents evaluate the phenomenon);

5. about senses (what respondents have seen, what they have touched, heard, smelled);

6. demographic questions about respondents' age, education and so on. 
Thus the authors of the article referring to own experience and scientists' insights formulated four questions by considering the methodology of the discussed six questions:

1. What knowledge and skills have you acquired while studying in nondegree study programme 'Pedagogy Studies'?

2. What is your opinion about the uniqueness of the programme?

3. How do the teachers work while delivering programme modules by distance method?

4. How have you evaluated the programme? This question contained additional questions:

- $\quad$ would you apply the acquired experience in your pedagogical practice?

- what would you suggest in the programme?

- $\quad$ would you and why recommend your colleagues and friends not possessing pedagogue's qualification to study in this programme?

The first question 'What knowledge and skills have you acquired while studying in non-degree study programme 'Pedagogy Studies'?' was answered by all 23 respondents. It is possible the obtained answers to group into four clusters (subcategories).

Table 1 'What knowledge and skills have you acquired while studying in non-degree study programme 'Pedagogy Studies'?

\begin{tabular}{|l|l|}
\hline Subcategory & Confirmative statements \\
\hline $\begin{array}{l}\text { A lot of theoretical } \\
\text { knowledge on teacher's } \\
\text { activity is acquired }\end{array}$ & $\begin{array}{l}\text { "I have got acquainted with different documents related } \\
\text { teacher's activity."; "I have learnt to plan my activity"; "I have } \\
\text { learnt to prepare and improve plans of the teaching subject by } \\
\text { adjusting them for a particular form"; "I have learnt to plan and } \\
\text { organize a lesson"; "I have got acquainted with contemporary } \\
\text { didactics (e.g., preparation of reporting with pupils)". }\end{array}$ \\
\hline $\begin{array}{l}\text { I have learnt to better } \\
\text { work with pupils }\end{array}$ & $\begin{array}{l}\text { "I have learnt to handle learning process"; "I have learnt to } \\
\text { include pupils into the activity"; "I have learnt to better assess } \\
\text { pupils' activity"; "I have known a lot about psychological } \\
\text { development of different age pupils". }\end{array}$ \\
\hline $\begin{array}{l}\text { Integrated knowledge } \\
\text { have been acquired }\end{array}$ & $\begin{array}{l}\text { "Interim accounts of most subjects relate to requirements for } \\
\text { final projects"; "When accounting for my performed } \\
\text { assignments, I could refer to the possessed and newly acquired } \\
\text { practical experience, reflect it"; "While performing the } \\
\text { pedagogical practice, I accumulated and analysed the } \\
\text { information, which later I could use for the final project". }\end{array}$ \\
\hline
\end{tabular}


Not only theoretical but also practical activity knowledge and skills have been acquired
"The programme gives a lot of time for the pedagogical practice (30 cr.)"; "Assignments of theoretical modules are related to the practical activity, they develop our practical skills"; "While performing the pedagogical practice at the educational institution, I could apply the acquired theoretical knowledge in the practice"; "The knowledge provided by a teacher about methodology of subject teaching is concrete, relates to pedagogue's activity and work very much".

The second question 'What is your opinion about the uniqueness of this programme?' was answered by all 23 respondents. Their answers can be grouped into two subcategories.

Table 2 'What is your opinion about the uniqueness of this programme?'

\begin{tabular}{|c|c|}
\hline Subcategory & Confirmative statements \\
\hline $\begin{array}{l}\text { The possibility to learn } \\
\text { in distance gives the } \\
\text { unique experience }\end{array}$ & $\begin{array}{l}\text { "Such programme is unique because I can coordinate my work } \\
\text { with my studies because my work agenda is very intensive"; } \\
\text { "Distant lectures allow saving time and money (it is not } \\
\text { necessary to go to the university on weekends), I can spend } \\
\text { more time with my family, children"; "On the computer desktop } \\
\text { I can see the lectures' material in the "Moodle' system, to } \\
\text { observe recorded lectures at the time convenient for me, even to } \\
\text { watch the transmitted lectures on the screen of one's smart } \\
\text { phone"; "The possibility is given for students to learn and } \\
\text { control their learning process"; "The lectures can be observed } \\
\text { directly and on the Internet. During the lectures I can put } \\
\text { questions in written for a teacher and at once get the answer } \\
\text { when a teacher delivers the lecture". "It is possible to get the } \\
\text { lectures on the Internet (because they are recorded) and observe } \\
\text { as many times as necessary. The records can be stopped in order } \\
\text { that you could better perceive and distinguish". "Individuals } \\
\text { living not only in Lithuania but also beyond its borders, as well } \\
\text { as mothers growing children at home and taking care of them } \\
\text { can study in the programme". }\end{array}$ \\
\hline $\begin{array}{l}\text { The unique possibility } \\
\text { to acquire theoretical } \\
\text { and practical } \\
\text { knowledge, abilities } \\
\text { necessary for a } \\
\text { pedagogue through a } \\
\text { study year. }\end{array}$ & $\begin{array}{l}\text { "Interesting and useful study subjects are chosen for the study } \\
\text { programme"; "The programme is so constructed that in it the } \\
\text { theoretical subjects fit the pedagogical practice". "The } \\
\text { programme is not similar to traditional pedagogical studies. It is } \\
\text { flexible, innovative". "The programme's modules are very } \\
\text { purposeful; namely, this is what a pedagogue needs while } \\
\text { working". "Only } 30 \text { percent of the pedagogical practice I carried } \\
\text { out at the educational institution where I work. Another part of } \\
\text { the practice I performed at another successfully working school } \\
\text { of my town. During the practice I could develop the knowledge } \\
\text { acquired during the theoretical lectures; the mentor and tutor } \\
\text { helped me". }\end{array}$ \\
\hline
\end{tabular}


The third question was 'How do teachers work while delivering the programme modules in distance?' All 23 respondents have answered and commented this question.

Table 3 'How do teachers work while delivering the programme modules in distance?'

\begin{tabular}{|l|l|}
\hline Subcategory & Confirmative statements \\
\hline $\begin{array}{l}\text { Competitive teachers } \\
\text { programme for this }\end{array}$ & \begin{tabular}{l} 
"The teachers are competitive and always hear the students, \\
communicate with them: it is possible to address a teacher and \\
get answers". "The teachers aspire and conduct consultations, to \\
which it is possible to come and directly communicate with a \\
teacher". "The teachers know their delivered subject, suggest \\
innovations". "Every teacher distinguishes in the methods \\
characteristic for him / her and his / her delivered subject". "A \\
lot of supplementary material is presented alongside lectures" \\
slides". \\
\hline "During lectures the teachers use the methods, which are \\
cheachers work \\
characteristic for the distance process, but also they present the \\
specific methods, which would fit teachers' work with pupils \\
during different lessons". "The teachers motivate the students to \\
work and they themselves work in impact and learning \\
paradigms". "Rich lists of literature are presented as well as \\
references to other sources for studies". "During lectures the \\
pictures and films are used". "Individual tasks are appointed \\
only when the material has been well explained and having \\
presented the requirements". "Guests are invited to the lectures: \\
famous pedagogues - practitioners, scientists, professors, the \\
pupils who successfully learn as well as their teachers". \\
"Lecturers from foreign universities visit and conduct the \\
lectures (Ecole d'Ingeneurs d'Angers, Oulu University of \\
Applied Sciences)".
\end{tabular} \\
\hline
\end{tabular}

The presented fourth question 'How do you evaluate this programme' was answered by all 23 students who were ready to graduate from the programme. All 23 respondents positively evaluated the programme.

Table 4 'How do you evaluate this programme'?

\begin{tabular}{|l|l|}
\hline Subcategory & Confirmative statements \\
\hline The study programme & $\begin{array}{l}\text { "The studies exceeded my expectations. I did not expect such } \\
\text { smooth and professional study process". "The study programme } \\
\text { is useful and necessary". "The modules are adjusted to the needs } \\
\text { of every student. Modules' assignments relate to practical } \\
\text { activity". "The prepared programme developing teachers" } \\
\text { competences is perfect and useful". "The study programme is } \\
\text { qualitative, relevant for a working teacher. } \\
\text { The programme is not dry, it contains a lot of practical activity". }\end{array}$ \\
\hline
\end{tabular}


Nijole Bankauskiene, Ramunè Masaitytè. Teachers' Training by Distance Teaching Method: the 15-Year Experience at Kaunas University of Technology

The students were additionally asked 'Are you going to apply the acquired experience? What would you suggest to change in the programme? Would you and why recommend this programme to your friends?'

Table 5 'Are you going to apply the acquired experience? What would you suggest to change in the programme? Would you and why recommend this programme to your friends?'

\begin{tabular}{|l|l|}
\hline Subcategory & Confirmative statements \\
\hline $\begin{array}{l}\text { In my pedagogical } \\
\text { practice I will apply } \\
\text { the experience } \\
\text { acquired during the } \\
\text { studies }\end{array}$ & $\begin{array}{l}\text { "I will follow the example of the activity of teachers, tutors and } \\
\text { mentors". "I will apply the methods of communication and } \\
\text { collaboration". "I will use the activity methods newly-known in } \\
\text { my lessons". "I will more reflect my activity". "I will apply the } \\
\text { experience of foreign scientists". "I will apply the experience of } \\
\text { 'action research'." }\end{array}$ \\
\hline $\begin{array}{l}\text { I suggest to change the } \\
\text { following elements in } \\
\text { the programme }\end{array}$ & $\begin{array}{l}\text { "Everything is considered in this programme and I would like to } \\
\text { change anything in this programme". "Examinations should be } \\
\text { performed only orally in order a student could better disclose his } \\
\text { / her insights and experience". "I suggest the entire time of } \\
\text { pedagogical practice to perform at own workplace but not after } \\
\text { half a year to search for another school". "The pedagogues, who } \\
\text { have more solid experience and work experience, should not } \\
\text { carry out their pedagogical practice. The system of credits } \\
\text { should be adjusted". "To include more theoretical lectures into } \\
\text { the modules 'Pedagogical Practice - 1' and 'Pedagogical } \\
\text { Practice - 2' in order the students, who do not work at school, as } \\
\text { well as their mentors would clearer perceive the essence of the } \\
\text { pedagogical practice". "The interwork of the students should be } \\
\text { created in order the students could much better collaborate". } \\
\text { "One has to uniform volumes of pedagogical practice hours in } \\
\text { autumn and spring terms". "Not to close the content of the } \\
\text { autumn term lectures in the "Moodle' system in order that the } \\
\text { students could follow during the spring term when preparing the } \\
\text { final project". }\end{array}$ \\
\hline
\end{tabular}

The question 'Would I and why recommend this programme to my friends and colleagues not possessing pedagogue's qualification?' was answered by 21 respondent out of 23 and they pointed out that they would recommend this programme to their friends and colleagues. 
Table 6 'Would I and why recommend this programme to my friends and colleagues not possessing pedagogue's qualification?'

\begin{tabular}{|l|l|}
\hline Subcategory & Confirmative statements \\
\hline $\begin{array}{l}\text { Subcategory 1: } \\
\text { convenient time and } \\
\text { schedule of studies }\end{array}$ & $\begin{array}{l}\text { "Due to convenient schedule of distance studies". "Due to } \\
\text { interesting, useful and high quality lectures". "It is adjusted for } \\
\text { future and already working teachers; it meets contemporary } \\
\text { requirements". "Ideal conditions for studies, constant } \\
\text { communication and collaboration". }\end{array}$ \\
\hline $\begin{array}{l}\text { Subcategory 2: respect } \\
\text { and attention for } \\
\text { students }\end{array}$ & $\begin{array}{l}\text { "Students' needs are considered". "Manifold respect and } \\
\text { attention for students. A student is both visible and heard. } \\
\text { Assistance for a student, consultations". "Programme managers } \\
\text { care for student's well-being and fortune". "Needs and } \\
\text { possibilities of working teachers and those having practice are } \\
\text { considered their possessed grades are scored)". "Those, who } \\
\text { pay for their studies in this programme, according to the KUT } \\
\text { Rector's order, the price was reduced by 40 \%". }\end{array}$ \\
\hline $\begin{array}{l}\text { Subcategory 3: } \\
\text { professional teachers }\end{array}$ & $\begin{array}{l}\text { "Pleasant, competitive and well-wishing teachers". "Impartial } \\
\text { teachers". "Attentive teachers". "Strict teachers". }\end{array}$ \\
\hline $\begin{array}{l}\text { Subcategory 4: } \\
\text { qualitative study } \\
\text { process }\end{array}$ & $\begin{array}{l}\text { "The programme is compact, flexible, lasts for one year, } \\
\text { student's time is saved up". "The teachers living in the most } \\
\text { distant Lithuanian places, as well as living in foreign countries, } \\
\text { can study in the programme". "Practical application of the } \\
\text { programme, the latest knowledge and researches in the field are } \\
\text { presented". }\end{array}$ \\
\hline
\end{tabular}

\section{Conclusions}

During 15 years, the KUT researchers in education have accumulated solid experience in training pedagogues by distance method. The programme changed in its volume and content: at present it includes 60 study credits, the balance between theoretical and practical part of the programme is vivid, and the individuals teaching 16 subjects at schools can study in this programme.

However, during all these years the students prepared their final project on the basis of action research. The distance teaching process has got richer and has developed in technological aspect from video conferences to lectures on the Internet. Today the students can see them directly on their computers or smart phones. The lectures are filmed. They and other worksheets are presented on the Moodle system.

23 respondents (the alumni of the academic year of 2014-2015) positively value the accumulated experience of KUT in training pedagogues by distance method. They emphasize the upgraded technologies and programme's uniqueness. 
Nijole Bankauskienè, Ramunè Masaitytè. Teachers' Training by Distance Teaching Method: the 15-Year Experience at Kaunas University of Technology

During one year students can acquire the knowledge necessary for a pedagogue. The internal logic of the programme is vivid, theoretical and practical sessions are in harmony, the study programme is qualitative, competitive and creative teachers work in it, teachers living and working not only in Lithuania but also abroad study in the programme.

588 individuals graduated from this programme and acquired pedagogue's qualification during the period of 2000-2015.

\section{References}

Freeman, R. (1997). Managing open Systems. London: Kogan Page.

Keegan, D. (1990). Foundations of Distance Education. London: Routlege.

Kraujutaitytė, L., \& Pečkaitis, S. J. (2003). Nuotoliniu studiju organizavimas: strategijos ir technologijos. Vilnius: Lietuvos teisès universitetas.

Ludlow, B. L. (1994). A Comparison of Traditional and Distance Education Models// Procedings of the Annual National Conference of the American Council on Rural Education. Austin:TX.

Patton, M. (1987). How to Use Qualitative Methods in Evaluations. California: Sage Publications, Inc.

Patton, M. (1990). Qualitative evaliution and research methods. SAGE Publications. Newbury Park London New Delhi.

Phare (2000). Atvirojo ir distancinio mokymosi medžiagos kūrimas. Atvirojo distancinio mokymo pagrindas. (https://www.nsc.vu.lt/metodika.htm).

Rumble, G. (1997). The Costs and Economics of Open and Distance Learning. London: Kogan Page.

Rupšienè, L. (2007). Kokybinio tyrimo duomenu metodologija. Klaipèda: Klaipèdos universiteto leidykla.

Rutkauskienè, D. (2007). Nuotolinio mokymosi desstytojo vadovas. Kaunas: Technologija.

Rutkauskienè, D., Targamadzè, A., \& Kovertaitė, V. R. (2003). Nuotolinis mokymasis. Kaunas:Technologija.

Rowntree, D. (1997). Making materials - Based Learning Work. - London: Kogan Page.

Targamadzè, A., Normantas, E., Rutkauskienè, D., \& Vidžiūnas, A. (1999). Naujos distancinio švietimo galimybès. Vilnius: Lietuvos neakivaizdinio švietimo centras.

Targamadzè, A., \& Petrauskienè, R. (2008). Nuotoliniu studiju kokybé technologiju kaitos sqlygomis. Kaunas: VDU.

Targamadzè, A. (2011). Technologijomis gristo mokymosi priemonès ir sistemos. Kaunas: Technologija.

Willis, B. (2000). Distance Education: an Overview. Distance Education at a Glance (http://www. Uidaho.edu/evo/dis1.htm). 